\title{
Response of Tomato (Solanum Lycopersicum) to Deficit Irrigation in Raya Valley, Northern Ethiopia
}

\author{
Yemane Mebrahtu $^{1 *} \quad$ Haftamu Tamiru ${ }^{2} \quad$ Ahmmed Mohammed ${ }^{1}$ \\ 1.Department Irrigation and Drainage, Ethiopian Institute of Agricultural Research (EIAR), Mekhoni \\ Agricultural Research Centre, Ethiopia.
}

2.Department Irrigation and Drainage, Ethiopian Institute of Agricultural Research (EIAR), Assosa Agricultural Research Centre, Ethiopia.

\begin{abstract}
Water scarcity, erratic rainfall distribution and better management of water are a major constraint for the production of food in arid and semi-arid areas. Therefore, to cope up this problem deficit irrigation and application of irrigation systems are important concerns to achieve the goal of reducing irrigation water use and increase water productivity without significant yield loss under scarce water resources. A field experiment was carried out at Mehoni Agricultural Research Center, Raya Valley of Ethiopia, with objective of to identify the level of deficit irrigation which allow achieving optimum yield and to investigate the effect of alternate, fixed and conventional furrow irrigation method on yield and water productivity. The treatment were three deficit irrigation levels (50, 75 and $100 \% \mathrm{ETc}$ ), and three furrow irrigation methods (conventional, alternate and fixed furrow) were laid out in a random complete block design (RCBD) with three replications. The highest yield was obtained from combination of convectional furrow irrigation method with $100 \%$ ETc, convectional furrow irrigation method with $75 \%$ ETc and alternative furrow irrigation method with $100 \%$ ETc respectively without statistically difference. The highest water productivity of tomato was recorded from alternative furrow irrigation method followed by fixed furrow irrigation method, while convectional furrow irrigation method was recorded the lowest water productivity. Therefore, it can be concluded that alternative furrow irrigation method with $100 \%$ ETC of irrigation level increased water productivity which solve a problem of water shortage without significance reduction in tomato yield.
\end{abstract}

Keywords: Deficit irrigation, Furrow methods, Irrigation level, Tomato, Water productivity

DOI: $10.7176 / \mathrm{JEES} / 10-6-04$

Publication date: June $30^{\text {th }} 2020$

\section{INTRODUCTION}

Irrigation is one of the most important inputs for agricultural production. Limited water resources and increasing water demand for industrial and urban settlements have caused decreases in the quantity and quality of agricultural water use (Osman et al, 2001).

Because of the limited water and high levelof competition, most irrigators in Ethiopia, especially these at tail of a scheme, allocation of irrigation water to the field is below the maximum crop water requirement for maximum yield (Lorite et al., 2007).

In the semi-arid areas of Ethiopia, water is the most limiting factor for crop production. In these areas where the amount and distribution of rainfall is not sufficient to sustain crop growth and development, an alternative approach is to make use of the rivers and underground water for irrigation. Satisfying crop water requirements, although it maximizes production from the land unit, does not necessarily maximize the return per unit volume of water (Oweis et al, 2000). Therefore, in an effort to improving water productivity, there is an increasing interest in judicious application of irrigation water, an irrigation practice which controls the spatial and temporal supply of water so as to promote growth and yield, and to enhance the economic efficiency of crop production.

Many investigations have been conducted to gain experiences in irrigation of crops to maximize performances, efficiency and profitability. However, investigations in water saving irrigation still are continued (Sleper et al., 2007). Nowadays, full irrigation is considered a luxury use of water that can be reduced with minor or no effect on profitable yield (Kang and Zhang, 2004).

Deficit irrigation is the application of less water than is required for potential ET and maximum yield, resulting in conservation of limited irrigation water (Musick, et al., 1994). Under conditions of scarce water supply and drought, deficit irrigation can lead to greater economic gains by maximizing yield per unit of water. Deficit irrigation as characterized by English (1990) has the fundamental goal to increase water use efficiency (WUE). Fereres and Soriano (2006) recently reviewed deficit irrigation and concluded that the level of irrigation supply should be $60-100 \%$ of full evapotranspiration (ET) needs in most cases to improve water productivity. Studies have shown that deficit irrigation significantly increased grain yield, ET and WUE as compared to rainfed winter wheat (Oweis, et al.; 2000). However, this approach requires precise knowledge of crop response to water as drought tolerance varies considerably by growth stage, species and cultivars.

The objective of the study was to identify the level of deficit irrigation which allow achieving optimum yield 
and to investigate the effect of alternate, fixed and conventional furrow irrigation systems on yield and water productivity.

\section{MATERIALS AND METHODS}

\subsection{Description of the experimental site}

This study was conducted at the research station of Mehoni Agricultural Research Centre (MehARC) in the Raya Valley, Northern Ethiopia, located $668 \mathrm{Km}$ from the capital Addis Ababa and about $120 \mathrm{Km}$ south of Mekelle, the capital city of Tigray regional state. Geographically, the experimental site is located at $12^{\circ} 51^{\prime} 50^{\prime \prime}$ North Latitude and $39^{\circ} 68^{\prime} 08^{\prime \prime}$ East Longitude with an altitude of $1578 \mathrm{~m}$.a.s.l. The site receives a mean annual rainfall of $300 \mathrm{~mm}$ with an average minimum and maximum temperature of 18 and $32^{\circ} \mathrm{C}$, respectively. The soil textural class of the experimental area is clay with $\mathrm{pH}$ of 7.1 to 8.1 (MehARC, 2015).
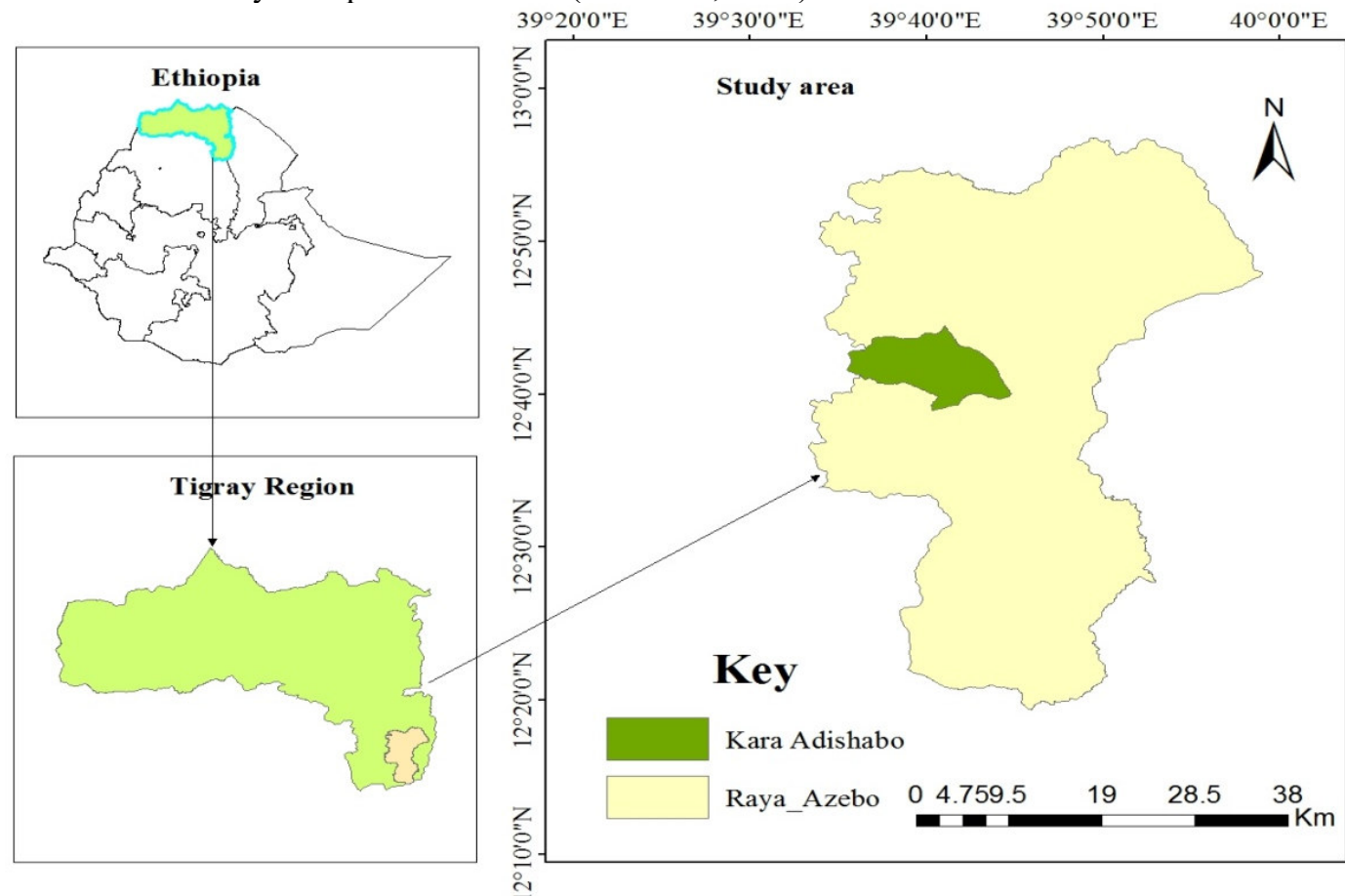

Figure 1. Map of the study area

\subsection{Climatic characteristics}

The average climatic data (Maximum and minimum temperature, relative humidity, wind speed, and sun shine hours) on monthly basis of the study area were collected from the near meteorological station. The potential evapotranspiration ETo was estimated using CROPWAT software version 8.

\subsection{Experimental treatments and design}

A fieldexperiment was carried out for three non-consecutive years. This experiment was laid out in RCBD with three replications. The treatments were included three furrow irrigation methods i.e alternate furrow irrigation (AFI), fixed furrow irrigation (FFI) and conventional furrow irrigation (CFI) and three levels of irrigation applications levels (100\%,75\% and 50\% ETc) combination of each other. Treatment having $100 \%$ ETc irrigation level and conventional furrow irrigation was considered as a control. All cultural practices were done in accordance to the recommendation made for the tomato. The optimal irrigation schedule (ETc) was computed with the aid of CROPWAT model. The amount of irrigation water applied at each irrigation application was measured using Parshall flume. 
Table 1. Treatment used in the experiment

\begin{tabular}{cl}
\hline Treatment & \multicolumn{1}{c}{ Combinations } \\
\hline T1 & Convectional furrow irrigated with $100 \% \mathrm{ETc}$ \\
T2 & Convectional furrow irrigated with $75 \%$ ETc \\
T3 & Convectional furrow irrigated with $50 \%$ ETc \\
T4 & Alternative furrow irrigated with $100 \%$ ETc \\
T5 & Alternative furrow irrigated with $75 \%$ ETc \\
T6 & Alternative furrow irrigated with $50 \%$ ETc \\
T7 & Fixed furrow irrigated with $100 \%$ ETc \\
T8 & Fixed furrow irrigated with 75\% ETc \\
T9 & Fixed furrow irrigated with 50\% ETc \\
\hline
\end{tabular}

Alternate furrow irrigation (AFI) meant one of the two neighboring furrows was alternately irrigated during consecutive irrigation events. Fixed furrow irrigation (FFI) meant that irrigation fixed to one of the two neighboring furrows. Conventional furrow irrigation (CFI) or traditional irrigation meant irrigating all furrows during consecutive watering.

\subsection{Data collection}

Yield data were collected from the four central rows out of six rows per plot to avoid border effect. Plant height, number of fruit per plant and cluster number were collected from selected eight plant sample of the four central rows.

\subsection{Water Productivity (WP)}

Water productivity was estimated as a ratio of fruit yield to the total ETc through the growing season and it was calculated using the following equation (Zwart and Bastiaanssen, 2004).

$$
\mathrm{WP}=\frac{\mathrm{Y}}{\mathrm{ETc}}
$$

Where, WP is water productivity $\left(\mathrm{kg} / \mathrm{m}^{3}\right), \mathrm{Y}$ crop yield $(\mathrm{kg} / \mathrm{ha})$ and ETc is the seasonal crop water consumption by evapotranspiration $\left(\mathrm{m}^{3} / \mathrm{ha}\right)$.

\section{Statistical analysis}

The three years yield and yield component data collected were subjected to ANOVA test using SAS software. The overall variability and effects of the treatment on yield and yield component parameters were considered as significant when $\mathrm{p}<0.05$. Least significant difference (LSD) test was applied for statistically significant parameters to compare means among the treatments.

\section{RESULTS AND DISCUSSION}

\subsection{Crop water requirement of tomato}

The water requirement of tomato was computed for the growing season using the CROPWAT 8 computer program with climate, soil and crop input data from the study area The values of ETo estimated using CROPWAT model based on climate parameters need to be adjusted for actual crop ET. The crop water requirement of the tested crop is calculated by multiplying the ETc with crop coefficient $(\mathrm{Kc})$.

According the seasonal irrigation water requirement of tomato was in the study area $529.9 \mathrm{~mm}$. This amount of water was needed for $100 \%, 75 \%$ and $50 \%$ ETc of irrigation level with convectional furrow irrigation method were $529.9 \mathrm{~mm}, 397.7 \mathrm{~mm}$, and $265.2 \mathrm{~mm}$ respectively. The amount of water was needed for $100 \%, 75 \%$ and $50 \%$ ETc of irrigation level with fixed and alternative furrow irrigation method were $265.2 \mathrm{~mm}, 199 \mathrm{~mm}, 132.8 \mathrm{~mm}$ and $124 \mathrm{~mm}$, respectively.

\subsection{Effect of irrigation levels and furrow method on yield and yield component}

\subsubsection{Effect of irrigation levels and furrow method on plant height}

Plant height of tomato was high significant $(\mathrm{P}<0.01)$ affected by the main effects of furrow irrigation methods and irrigation level, but not significantly $(\mathrm{P}<0.05)$ affected by the interaction effects of the treatments $($ Table 2$)$. Significantly higher plant height of tomato 43.04 and $42.9 \mathrm{~cm}$ was recorded for $100 \%$ ETc (full irrigation) and $75 \%$ ETc of irrigation depth of water applied respectively. 50\% ETc of irrigation level of water applied recorded the lowest plant height of $40.6 \mathrm{~cm}$.

The highest plant height was $45.1 \mathrm{~cm}$ recorded by conventional furrow irrigation method followed by alternative furrow irrigation systems with the value of $40.7 \mathrm{~cm}$. The lowest plant height was observed from the treatment of fixed furrow irrigation method with value of $40.6 \mathrm{~cm}$. Among the treatment of Alternative and fixed furrow irrigation method there were no significances difference.

this result was in line with the findings of J.C Paul, et al., (2013) and S.K Biswas et al, (2014). The highest increase in vegetative growth might be due to the availability of soil moisture. 
The results of this study are reliable with those finding of Zinabu. (2019) who found that deficit irrigation reduces plant height of tomato, which in turn affects yield. The finding of this study is also in agreement with those of Yemane et al. (2018), who reported that water deficit significantly reduced plant height.

\subsubsection{Effect of irrigation levels and furrow method on number of fruits per plant}

The analysis of variance the interaction of furrow irrigation methods and irrigation level has shown that, there was not significant difference $(\mathrm{P}<0.05)$ on number of fruit per plant, but the main effect of furrow irrigation methods and irrigation levels was shown significances differences (Table 2).

As shown in Table 2, the higher number of fruit per plant of tomato 51.4 was recorded for $100 \%$ ETc of irrigation level and followed by $75 \%$ ETc. The lowest number of fruit plant was observed from $50 \%$ ETc of irrigation level with the value of 45.8. Statically the was no significant differences between $100 \%$ and $75 \%$ ETc of irrigation level.

The higher number of fruit per plant was observed from the treatment convectional furrow irrigation method 52.4 and alternative and fixed furrow irrigation method were recorded the lowest number of fruit per plant. The result might be because of the reason that high irrigation levels increased photosynthetic area of the plant (height of plants and number of leaves), which increased the number of fruit per plant and increased fruit yield. The reduction of number of fruit under deficit irrigation was mainly attributed to reduction of water rather than to reduction of assimilates imported into the fruit Ho JC (1996). Similar finding was obtained Selamawit (2017), who reported that deficit irrigation significantly reduced number of fruit per plant height.

\subsubsection{Effect of irrigation levels and furrow method on unmarketable and total yield of tomato}

Significantly higher unmarketable and total yield of tomato were recorded when $50 \%$ ETc and $100 \%$ ETc irrigation level applied with the value 6.0 and 39.91 tone/ha respectively. In the other hand, the lowest unmarketable and total yield of tomato were observed from the treatment of $100 \%$ and $50 \%$ ETc of irrigation level with the result of 5.02 and 35.72 ton/ha respectively. Unmarketable yield of $100 \%$ and $75 \%$ ETc irrigation level was not have significant differences.

The highest total yield of tomato was obtained from the treatment of convectional furrow irrigation method (39.13 ton/ha) followed by alternative furrow irrigation method (37.51 ton/ha). Statistically higher unmarketable yield was recorded from fixed and alternative furrow irrigation method with the value of 62.68 and 59.3 ton/ha respectively. The lowest unmarketable yield of tomato was observed from convection furrow irrigation method (Table 2).

The increased total yield by applying full (no deficit) irrigation could have better performance on vegetative growth like plant height, number of fruit and cluster per plant which increase photosynthetic capacity of the plant, which in turn can improve to increment in total bulb yield.

The results of this study was agreed with the finding of (Kebede, 2003) who reported that stressed onion plants may bulb too early, produce small-sized bulbs and bulb splits and, thus, produce high amount of unmarketable yield. This could be due to low rate of transpiration caused by stomata closer under moisture stress condition which brought about reduced photosynthesis and poor bulb growth and developments.

As the irrigation level increased, the total yield increased. This result was also in agreement with the findings of Ferreira and carr, (2002).

Table 2. Effect of furrow irrigation methods and irrigation levels on plant height $(\mathrm{cm})$, Number of fruit per plant, Unmarketable yield (ton/ha) and Total yield (ton/ha) of tomato

\begin{tabular}{|c|c|c|c|c|}
\hline Furrow methods & PH & NFPP & UMY & TY \\
\hline CFI & $45.1^{\mathrm{a}}$ & $52.4^{\mathrm{a}}$ & $4.32^{b}$ & $39.13^{\mathrm{a}}$ \\
\hline AFI & $40.7^{\mathrm{b}}$ & $48.1^{\mathrm{b}}$ & $5.93^{\mathrm{a}}$ & $37.51^{\mathrm{b}}$ \\
\hline FFI & $40.6^{\mathrm{b}}$ & $46^{\mathrm{b}}$ & $6.27^{\mathrm{a}}$ & $35.91^{\mathrm{c}}$ \\
\hline $\operatorname{LSD}(P=0.05)$ & 2.1 & 3.7 & 0.56 & 13.97 \\
\hline \multicolumn{5}{|l|}{ Irrigation level } \\
\hline $100 \%$ & $43.04^{\mathrm{a}}$ & $51.4^{\mathrm{a}}$ & $5.02^{b}$ & $39.91^{\mathrm{a}}$ \\
\hline $75 \%$ & $42.9^{\mathrm{a}}$ & $49.2^{\mathrm{ab}}$ & $5.51^{\mathrm{ab}}$ & $38.15^{\mathrm{b}}$ \\
\hline $50 \%$ & $40.6^{\mathrm{b}}$ & $45.8^{\mathrm{b}}$ & $6.00^{\mathrm{a}}$ & $35.72^{c}$ \\
\hline LSD $(P=0.05)$ & 2.1 & 3.7 & 0.57 & 13.9 \\
\hline CV (\%) & 5.06 & 7.7 & 10.3 & 5.7 \\
\hline
\end{tabular}

*Means followed by different letters in a column differ significantly and those followed by the same letter are not significantly different at $P<0.05 ; \mathrm{LSD}=$ least significant difference; $C V=$ Coefficient of variation. 3.2.4. Effect of irrigation levels and furrow methods on marketable yield

Marketable yield of tomato was highly significantly affected $(P<0.01)$ by the furrow irrigation methods and irrigation level (Table 3). Similarly, interaction effect of furrow irrigation methods and irrigation level was observed significant differences on the marketable yield of tomato.

The maximum marketable yield of tomato was observed at $100 \%$ ETc with convectional furrow irrigation method (37.82 ton/ha) and the minimum yield recorded at 50\% ETc with fixed furrow irrigation method $(28.35$ 
ton/ha). Statistically there was no significance differences between the interaction of $100 \%$ ETc with convectional furrow irrigation method, $75 \%$ ETc with convectional furrow irrigation method and $100 \%$ ETc with alternative furrow irrigation method.

Higher marketable yield of tomato was recorded from $100 \%$ ETc followed by $75 \%$ ETc irrigation level with the value of 35.25 and 32.71 ton/ha respectively. Significantly lower bulb yield of 29.72 ton/ha was recorded with $50 \%$ of irrigation level.

Among the furrow irrigation method treatments, conventional furrow irrigation method produced the highest yield of 34.86 ton/ha, alternate furrow irrigation method $(32.05$ ton/ha) while fixed furrow irrigation method gave the lowest yield of tomato with the value 30.77 ton $/ \mathrm{ha}$.

This result was in lined with the finding of Sepaskhah and Ghasemi (2008), who reported that small amount of applied water reduced yield in every other furrow irrigation (AFI and FFI) as compared to CFI due to water stress, when the same irrigation frequency was applied which supported the result of this research.

This result is supported by finding of Selamawit (2017) and Tamirneh (2018), who reported that deficit irrigation reduced marketable yield of tomato as compare $100 \%$ crop water requirement.

Table 3. Interaction effects of furrow irrigation methods and irrigation levels on marketable yield (ton/ha) of tomato

\begin{tabular}{|c|c|c|c|c|}
\hline \multirow[t]{2}{*}{ Furrow methods } & \multicolumn{4}{|c|}{ Irrigation level } \\
\hline & $100 \%$ & $75 \%$ & $50 \%$ & Mean \\
\hline CFI & $37.82^{\mathrm{a}}$ & $35.36^{\mathrm{ab}}$ & $31.39^{\mathrm{cd}}$ & 34.86 \\
\hline AFI & $35.16^{\mathrm{ab}}$ & $31.57^{\mathrm{cd}}$ & $29.41^{\mathrm{de}}$ & 32.05 \\
\hline FFI & $32.76^{\mathrm{cd}}$ & $31.21^{\mathrm{cd}}$ & $28.35^{\mathrm{e}}$ & 30.77 \\
\hline Mean & 35.25 & 32.71 & 29.72 & \\
\hline $\begin{array}{l}\text { LSD (0.5) } \\
\text { (0.5) }\end{array}$ & \multicolumn{2}{|c|}{2.66} & & \\
\hline CV (\%) & \multicolumn{2}{|c|}{4.8} & & \\
\hline
\end{tabular}

*Means followed by different letters in a column differ significantly and those followed by the same letter are not significantly different at $P<0.05 ; \mathrm{LSD}=$ least significant difference; $C V=$ Coefficient of variation.

\subsection{Effect of irrigation levels and furrow methods on water productivity}

The analysis of variance indicated that irrigation levels and furrow method was high significant $(p<0.01)$ affected by the interaction and main effect of each treatment on water productivity of tomato (Table 4).

The highest value of water productivity was recorded from the interaction of $50 \%$ ETc with alternative and fixed furrow irrigation method with the result of $\left(22.4\right.$ and $\left.21.4 \mathrm{~kg} / \mathrm{m}^{3}\right)$. On the other hand, the lowest water productivity was obtained from the interaction of $100 \%$ ETc of irrigation level with convectional furrow irrigation method $\left(7.2 \mathrm{~m}^{3} / \mathrm{ha}\right)$.

Irrigation level, in its main effect, increased water productivity from $50 \% \mathrm{ETc}$ to $100 \%$ ETc irrigation level. Higher water productivity of tomato was obtained from $50 \%$ ETc followed by $75 \%$ ETc of irrigation level with the value of 18.57 and $13.53 \mathrm{~kg} / \mathrm{m}^{3}$ respectively. As compare the other treatment, full irrigation $(100 \%$ ETc) of irrigation level was recorded the lowest water productivity $\left(10.83 \mathrm{~kg} / \mathrm{m}^{3}\right)$.

Significantly higher water productivity of tomato was recorded when alternative furrow irrigation method applied with $17.06 \mathrm{~kg} / \mathrm{ha}^{3}$ and followed by fixed furrow irrigation method with $16.52 \mathrm{~m}^{3} / \mathrm{ha}$, while the lowest water productivity was recorded when convection furrow irrigation applied with the value of $9.34 \mathrm{~kg} / \mathrm{m}^{3}$.

The results of this research are in agreement with Yemane et al. (2018), who reported that water productivity values decreased with increasing irrigation level. In line with this result, Samson and Ketema (2007) reported that deficit irrigations increased the water use efficiency.

Table 4. Interaction effects of furrow irrigation system and irrigation levels on water productivity $\left(\mathrm{kg} / \mathrm{m}^{3}\right)$ of tomato

\begin{tabular}{lllll}
\hline Furrow methods & \multicolumn{3}{c}{ Irrigation level } \\
\cline { 2 - 5 } & $\mathbf{1 0 0 \%}$ & $\mathbf{7 5 \%}$ & $\mathbf{5 0 \%}$ & Mean \\
\hline CFI & $7.2^{\mathrm{e}}$ & $8.9^{\mathrm{d}}$ & $11.92^{\mathrm{c}}$ & $\mathbf{9 . 3 4}$ \\
AFI & $15.8^{\mathrm{b}}$ & $14.99^{\mathrm{c}}$ & $22.4^{\mathrm{a}}$ & $\mathbf{1 7 . 0 6}$ \\
FFI & $12.49^{\mathrm{c}}$ & $15.7^{\mathrm{b}}$ & $21.39^{\mathrm{a}}$ & $\mathbf{1 6 . 5 2}$ \\
Mean & $\mathbf{1 0 . 8 3}$ & $\mathbf{1 3 . 5 3}$ & $\mathbf{1 8 . 5 7}$ & \\
\hline
\end{tabular}

LSD (0.5) 1.32

CV (\%) $\quad 5.37$

*Means followed by different letters in a column differ significantly and those followed by the same letter are not significantly different at $P<0.05 ; L S D=$ least significant difference; $C V=$ Coefficient of variation. 


\section{CONCLUSION}

It could be concluded that, In the study areas water is a limiting factor and a combination of alternative furrow irrigation method with $100 \%$ ETc irrigation level gave higher water productivity without significance tomato yield reduction, while the applied water in alternative furrow irrigation was reduced the amount of irrigation water and increasing the irrigated land by $50 \%$ than the convectional furrow irrigation method.

\section{CONFLICT OF INTERESTS}

The authors have not declared any conflict of interests.

\section{ACKNOWLEDGMENTS}

The authors are grateful to Ethiopian Institute of Agricultural Research, for providing funds for the experiment and technical support. The authors also very grateful to Mehoni Agricultural research centre for all staff of Natural Resources Management Research core process for giving us support in field management, suggestion and technical guidance during the course of the study experiment.

\section{REFERENCES}

Ferreira, T.C and Carr, M.K.V. 2002. Response of potatoes (Solanum tuberasum L.) to irrigation and nitrogen in a hot, dry climate: I. water use. Field Crops Research, Vol. 78, p. 51-64.

Ho J.C. 1996. The mechanism of assimilate partitioning and carbohydrate compartmentation in fruit in relation to the quality and yield of tomato. J. Exp. Bot. 1996; 47:1239-1243.

J.C. Paul., J.N. Mishra., P.L. Pradhan and B. Panigrahi. 2013. Effect of drip and surface irrigation on yield, WaterUse-efficiency and economics of capsicum (capsicum annuml). Grown under mulch and non-mulch conditions in eastern coastal India. European Journal of Sustainable Development 2, 1, 99-108.

Kang, S.Z., and J.H. Zhang. 2004. Controlled alternate partial root-zone irrigation: its physiological consequences and impact on water use efficiency. Jour. of Experimental Botany, 55: 2437-2446.

Kebede Woldetsadik. 2003. Shallot (Allium cepa var. ascalonicum) responses to plant nutrient and soil moisture in a sub- humid tropical climate. Journal of Horticultural sciences and Biotechnology, 78(4):549555.

Lorite, I.J., Mateos L., Orgaz F., Fresses E. 2007. Assessing deficit irrigation strategies at the level of an irrigation district. Agricultural Water Management 91:51-60. http://dx.doi.org/10.1016/ j.Agwat. 2007.04.005.

MehARC. (Mehoni Agricultural Research Center, Land and water research process). 2015. Annual research report, Maichew, Tigray, Ethiopia.

Osman, Y., Oner, C., Demet, U. and Hasan, B. 2001. Irrigation scheduling of Drip-irrigated Tomato using A pan evaporation, Turkey Journal of Agriculture, 26(2002)171-178.

Oweis, T. Zhang, H and Pala, M. 2000. Water use efficiency of rainfed and irrigated bread wheat in a Mediterranean environment. Agronomy Journal 92: 231-238.

Samson and Tilahun. 2007. Regulated deficit irrigation scheduling of onion in a semiarid region of Ethiopia, Agricultural Water Management, vol. 89.

Selamawit Bekele. 2017. Response of Tomato to Deficit Irrigation at Ambo, Ethiopia. Journal of Natural Sciences Research. Vol.7 No.23 2017.

S.K. Biswas., A.R. Akanda., M.S. Rahman, and M.A. Hossain. 2014. Effect of drip irrigation and mulching on yield, water-use efficiency and economics of tomato. Bangladesh Agricultural Research Institute, Gazipur, Bangladesh. Vol. 61, 2015, No. 3: 97-102.

Sleper, D.A., S.L. Fales, and M.E. Collins., 2007. Foreword. In: Irrigation of agricultural crops (R.J. Lascano and R.E. Sojka, eds.), 2nd edition, Agronomy MonograpH no. 30. ASA-CSSA-SSSA publishing, 664p.

Sepaskhah, A.R., and Ghasemi, M. 2008. Every-other-furrow irrigation with different intervals for sorghum. Pak. J. Biol. Sci. 11(9): 1234-1239.

Tamirneh Kifle., 2018. Evaluation of Tomato Response to Deficit Irrigation at Humbon Woreda, Ethiopia. Journal of Natural Sciences Research. Vol.8, No.15, 2018.

Yemane M., Abraham W., and Solomon H. 2018. Response of onion (Allium cepa 1.) to deficit irrigation under different furrow irrigation water management techniques in Raya Valley, Northern Ethiopia. African Journal of Plant Science. Vol. 12(5), pp. 105-113.

Zinabu A. 2019. Evaluation of Alternate, Fixed and Conventional Furrow Irrigation Systems with Different Water Application Level on Onion Yield in Dubti, Afar, Ethiopia. Industrial Engineering Letters. Vol.9, No.5, 2019. 